Article

\title{
Reviewing the Poyang Lake Hydraulic Project Based on Humans' Changing Cognition of Water Conservancy Projects
}

\author{
Yao $\mathrm{Wu}^{1,2}$, Lidan Guo ${ }^{3,4,5, *}$, Ziqiang Xia ${ }^{1,3}$, Peiran Jing ${ }^{4}$ and Xunzhou Chunyu ${ }^{1}$ \\ 1 College of Hydrology and Water Resources, Hohai University, Nanjing 210098, China; \\ wuyao@jxsl.gov.cn (Y.W.); zqxia@hhu.edu.cn (Z.X.); zodiacnix@163.com (X.C.) \\ 2 Poyang Lake Hydro Project Construction Office of Jiangxi Province, Nanchang 330046, China \\ 3 International River Research Centre, Hohai University, Nanjing 211100, China \\ 4 Business School, Hohai University, Nanjing 211100, China; jingpeiran1997@126.com \\ 5 Jiangsu Provincial Collaborative Innovation Center of World Water Valley and Water Ecological Civilization, \\ Nanjing 211100, China \\ * Correspondence: ldguohhu@163.com; Tel.: +86-25-6851-4728
}

Received: 14 March 2019; Accepted: 30 April 2019; Published: 6 May 2019

\begin{abstract}
Water conservancy projects occupy an extremely important status in human development history. Human cognition about water conservancy projects has been in constant evolution along with the changing relationship between humans and nature (water). Based on a literature review, this study provides a systemic summary of the evolution of the human need for water resources and of water conservancy projects, as well as the equilibrium between humans and nature (river and lake ecosystems). More importantly, the transformation of cognition concerning the governance of nature and river and lake ecosystems is reviewed. Taking the perspective of modern rationalism on water conservancy projects, four major changes in human cognition are identified. Further, the most salient water-related issues arising from China's largest freshwater lake, Poyang Lake, are analyzed and the history and predicament of its governance are described. This is accompanied by a discussion on the countermeasures. Finally, based on the evolution of the human-water relationship and cognitive transformation concerning water conservancy projects, several suggestions are proposed for the planned construction of the Poyang Lake Hydraulic Project. The conclusions of this paper shed new light on the principles of water governance and water conservancy project construction in a new era that has witnessed a growing conflict between socioeconomic development and the water environment. Our suggestions are also valuable for the governance of Poyang Lake.
\end{abstract}

Keywords: water conservancy projects; Poyang Lake Hydraulic Project; cognitive transformation; principles of water governance

\section{Introduction}

Water is the source of life, an essential element of the production, and the foundation of ecology. Water is the material basis of survival and development of humans and other organisms. Water conservancy is a prerequisite and guarantee for economic and social development. Developing water conservancy and eliminating water disasters have long been high priorities in state affairs management and national security. Rivers and lakes are basic resources endowed by nature for humans. However, water resources not only serve humans by providing products, regulating the environment, and shaping the culture, but also cause flood disasters. As human awareness of the benefits and drawbacks of water develops, water governance practices evolve. Water conservancy projects are an important means of water governance. For a long time, water conservancy projects have been critical to economic and social 
development and people's welfare. Since the 1950s, there has been vigorous development of water resources and electric power. At present, China has reached a new historical height in hydropower construction [1,2], and current water conservancy projects can basically meet the needs. However, as the contradictions between economic and social development and water resources are becoming more pronounced, disordered human activities worldwide have caused an aggravating impact on the ecological environment. The eco-environmental problems caused by hydropower construction have also received unprecedented attention from the international community [3]. Therefore, current water conservancy project construction has encountered a bottleneck. The advantages and disadvantages of water conservancy projects, as well as the potential eco-environmental impacts of such projects, have gradually become hot issues in the international community.

For centuries, hydraulic engineers were at the forefront of science. Sustainability and environmental management have currently become "fashionable" topics [4]. So, is there a need for further hydraulic engineering? What perspective should we take on water conservancy projects in the future? There is a growing consensus that water conservancy projects, while bringing benefits in flood prevention, water supply, irrigation, and electricity generation, have a negligible eco-environmental impact. Therefore, people have begun to think more deeply about water conservancy projects (including those already built or planned to be built). As far as the philosophy of water conservancy is concerned, there are two schools of thought, drawing on the advantages or avoiding the disadvantages [5]. The former fully recognizes the benefits of water conservancy in flood prevention, irrigation, water supply, electricity generation, shipping, and clean energy, and the latter highlights the adverse eco-environmental impact. For the latter, the disadvantages of water conservancy outweigh its advantages, which serve as justification for the protection of the original ecology of rivers and opposition to hydropower development. In a word, along with the constant progress in social production, economic conditions, and technology, the demands for water conservancy also vary, and human cognition about water conservancy projects has changed dramatically over time. In order to assess water conservancy projects more wisely, it is necessary to understand the evolution of man's relationship with nature (rivers and lakes) throughout history.

Poyang Lake, China's largest freshwater lake, is located in northern Jiangxi Province and the southern bank of the middle reach of the Yangtze River. Poyang Lake receives water from five major rivers upstream: The Gan, Fu, Xin, Rao, and Xiu Rivers. After regulation and storage, the water of Poyang Lake flows into the Yangtze River through the head of the lake. Poyang Lake is a typical water-passing and river-injecting alternately filled and seasonal lake. Because of its unique geographic location and richly endowed natural conditions, Poyang Lake has high social, economic, and ecological value for the entire Jiangxi Province and Yangtze River Basin. However, due to human activities in modern times (e.g., Three Gorges hydraulic projects in the Yangtze River and other hydraulic projects in Poyang Lake Basin), flood and drought disasters have occurred frequently in Poyang Lake in recent years. Other environmental problems, such as wetland vegetation degradation, land desertification, lake shrinkage, and biodiversity reduction are becoming increasingly severe. Poyang Lake Basin has a weak ecosystem service function, which has considerably restricted the stability of economic and social development near the lake. This is also a major factor impeding the sustainable development of the entire Yangtze River Basin [6]. In order to solve the water-related issues in the Poyang Lake area, the people of Jiangxi Province have carried out a long-term demonstration of the lake control project. The project has been in limbo because of disagreements between hydraulic specialists and environmentalists. In this context, the following questions are worth pondering: Is the lake control hydraulic project necessary to handle these water-related problems? How should we position the project to be built? What kind of hydraulic project will be most favorable for sustainable development of the drainage basin?

Throughout most of the existing literature, many scholars have analyzed achievements in China's water conservancy construction [1] and development stage [2], and some experts have studied water projects from the perspective of ecology [3] or harmony between people and water [5]. Others 
focus on relationships between different types of land use with water pollutant parameters in river basins $[7,8]$. However, there are few studies that delve into human cognition about and attitudes toward water conservancy measures (engineering) from the perspective of the evolution of the human-water relationship. Poyang Lake has received great international attention, due to its control project proposals. Most of these focus on specific problems in the Poyang Lake basin in terms of water conservancy development [9], engineering impact [10], ecology [6], hydrodynamic and water quality [11,12], and so on. However, there is a lack of in-depth study of the underlying philosophy of lake management.

To find answers to the above questions, this paper systematically reviews the evolution of the types and functions of water conservancy projects, as well as human cognitive transformation regarding water conservancy. On this basis, we further analyze the need for a construction and demonstration process of the Poyang Lake Hydraulic Project. Finally, theoretical support for the sustainability of construction and operational management of the hydraulic project constructed under this new trend is proposed. Our research lays a basis for demonstrating the Poyang Lake Hydraulic Project construction, operation, and scheduling plan. The purpose is to study human cognition of the role of water conservancy projects in river and lake governance based on revealing the evolution of the human-water relationship, so as to guide the future development and utilization of water resources and management of rivers and lakes. It should be noted that water quality is an important element in overall ecosystem health, and the study area has had problems, due to agricultural nonpoint pollution, domestic sewage, and industrial discharge. However, according to Li [11] and Li et al. [12], major water quality parameters, including Total Nitrogen (TN), Ammonia-Nitrogen $\left(\mathrm{NH}_{3}-\mathrm{N}\right)$, Total Phosphorus (TP), and Dissolved Oxygen (DO) are found to be negatively correlated with water level in the main lake area of Poyang Lake, and optimizing water level management during the dry season can help to reduce the risk of eutrophication. Therefore, the premise of this study is that regulating the water level in the lake can help to control the water quality issue, and the research focus is on water quantity rather than water quality.

\section{Evolution of Water Conservancy Projects and Human Cognitive Transformation Concerning Water Conservancy}

Water resources in nature are distributed unevenly in space and time. To fully exploit water resources and to prevent and control drought and flood disasters, water conservancy projects that can allocate and control the surface water and groundwater may be needed. Water conservancy projects can satisfy various needs in social and production life, transportation, energy supply, environmental protection, and ecological construction. As the human need for water resources keeps expanding, the types and functions of water conservancy projects are also becoming diversified.

\subsection{Evolution of Water Conservancy Projects Based on Human Needs}

\subsubsection{Evolution of Human Need for Water Resources}

In the development of the human-nature (water) interaction, there has been a transition from conforming/adapting to nature to transforming/conquering nature and, further, to selfreflection/coexistence with nature. By assigning different roles to water conservancy projects, humans satisfy their own needs while constantly adjusting their relationship with water. Generally speaking, the human attitude toward water has undergone a change from "preventing and controlling water hazards" to "developing water conservancy and eliminating flood disasters" (which is combined with simple forms of water resource utilization, such as water supply, irrigation, water interception, and discharge), and finally to "comprehensive utilization" (e.g., hydropower, recreation and entertainment, fishery and aquaculture, and shipping) (see Figure 1). Humans and nature are always part of one life community, and humans must always respect, adapt to, and protect nature. 


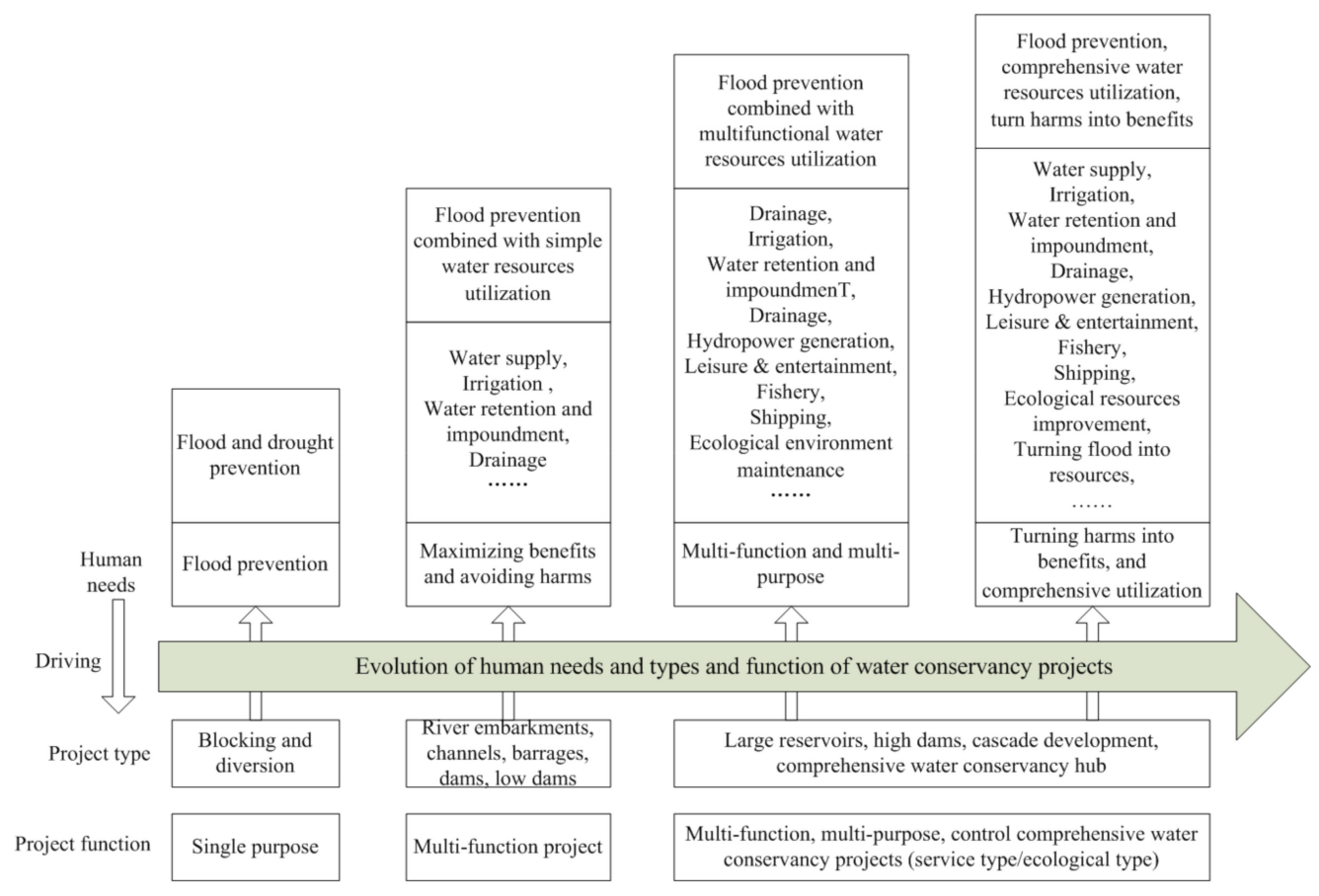

Figure 1. Evolution of human need for water resources and types and functions of water conservancy projects.

\subsubsection{Changes in Types and Functions of Water Conservancy Projects}

As far as the function of water conservancy projects is concerned, there has been a transition from single-function (e.g., flood prevention, irrigation, or shipping) to multifunction (Figure 1). Ancient Egyptians and Babylonians built a series of hydraulic projects, such as water diversion and irrigation projects, dams, and canals. In ancient China, Da Yu supervised the construction of many hydraulic projects, including Que Bei, Zhengguo Canal, Dujiangyan Irrigation System, Ling Canal, and Beijing-Hangzhou Grand Canal [9]. Given the limited social, economic, and technological development levels of ancient times, people could only hope to solve water-related problems by building single-function hydraulic projects, and very few projects could perform a variety of functions [13]. Therefore, these projects only fulfilled single functional needs, such as flood prevention, irrigation, or shipping. As human society has developed, single-function hydraulic projects have fallen short of the requirements for reasonable water resource governance and exploitation. In a word, they can no longer support social and economic development. In modern times, there has been an ever-growing need for water as the society and the industrial structure of the economy, professional knowledge, and engineering technology are progressing rapidly. In addition to irrigation and shipping, other functions of water resources, such as hydropower, pest control, ecological maintenance, aquaculture, and tourism, are also utilized through water conservancy projects. It has gradually become established that only comprehensive water conservancy projects can handle complex and systemic water-related problems while satisfying the diverse demands on water resources in the easiest way. Modern times have witnessed the building of water conservancy projects intended to fulfill multiple benefits [14], such as Hoover Dam in the US [15], Aswan Dam [16] in Egypt, and the Three Gorges Hydroelectric Complex project in China [17]. Apparently, human requirements for water conservancy projects have changed from single to multiple.

Accordingly, the types of water conservancy projects have evolved from the earliest functions of blockage and diversion to canals, dams, water gates, dikes, and low dams to high dams and large reservoirs and cascade hydropower stations. Now there are multipurpose hydraulic projects (Figure 1). In the past, a greater emphasis was placed on blockage than on diversion in flood control, and dikes and dams were constructed to ward off the water [18]. For example, in the Ming and Qing Dynasties, people 
living in the middle and lower reaches of the Yangtze River, especially those near Poyang Lake, built dikes and dams along the lake to fight against flood and to protect the farmland [14]. Later, water-retaining structures, such as reservoirs appeared. Apart from stopping floods, reservoirs can also retain surplus water for other uses, such as hydropower generation and water supply [19]. The concept of flood resource utilization has become increasingly known as more water-related problems have emerged in recent years, such as water shortages, frequent flood disasters, water environment pollution, and aquatic ecosystem deterioration, and also as ecological water conservancy construction is developing rapidly.

In general, based on their intended use, water conservancy projects can be divided into several types [20], as shown in Table 1. According to the objective of service, water conservancy projects are divided into flood control, hydropower, irrigation and drainage, navigation channel and port, urban water supply and drainage, water and soil conservation, and environmental hydraulic projects. According to their effects on water, water conservancy projects are divided into water storage, water diversion, drainage, water-lifting, water transfer, and water purification and sewage treatment projects.

Table 1. Classification of water conservancy projects.

\begin{tabular}{|c|c|c|}
\hline Classification Criterion & Type of Project & Function \\
\hline \multirow{7}{*}{ Service } & Flood control & $\begin{array}{l}\text { Defend and control storm flood hazard; store, } \\
\text { regulate, and discharge flood; reduce } \\
\text { flood-related loss }\end{array}$ \\
\hline & Hydropower & Convert hydropower into electric power \\
\hline & Irrigation and drainage & $\begin{array}{l}\text { Serve agricultural irrigation and drainage, } \\
\text { regulate local water conditions, prevent } \\
\text { drought and flood disasters }\end{array}$ \\
\hline & Navigation channel and port & Create and improve shipping conditions \\
\hline & Urban water supply and drainage & $\begin{array}{l}\text { Supply urban industrial and domestic water, } \\
\text { treat and eliminate sewage and rainwater }\end{array}$ \\
\hline & Water and soil conservation & $\begin{array}{l}\text { Prevent and control water soil erosion and } \\
\text { water pollution, maintain ecological balance }\end{array}$ \\
\hline & Environmental hydraulic & $\begin{array}{l}\text { Protect aquatic ecosystem and water resources, } \\
\text { control water pollution }\end{array}$ \\
\hline \multirow{6}{*}{ Effect on water } & Water storage & $\begin{array}{l}\text { Intercept rivers and lakes to form water } \\
\text { reservoirs or dammed water }\end{array}$ \\
\hline & Water intake & $\begin{array}{l}\text { Divert water from rivers and reservoirs into } \\
\text { water conveyance structures, such as canals, } \\
\text { tunnels, water intake sluices }\end{array}$ \\
\hline & Drainage project & $\begin{array}{l}\text { Collect (process) wastewater produced by } \\
\text { human production activities and surplus } \\
\text { surface water and groundwater (lowering } \\
\text { groundwater table) }\end{array}$ \\
\hline & Water-lifting & $\begin{array}{c}\text { Use water pumping stations and pipelines to } \\
\text { raise low-lying water }\end{array}$ \\
\hline & Water transfer & $\begin{array}{l}\text { Use pipelines for water transfer to meet } \\
\text { irrigation, hydropower, water supply, and } \\
\text { ecological needs }\end{array}$ \\
\hline & $\begin{array}{l}\text { Water purification and } \\
\text { sewage treatment }\end{array}$ & $\begin{array}{l}\text { Employ engineering means to purify water and } \\
\text { restore the health of the aquatic ecosystem, so } \\
\text { that wastewater can meet water quality } \\
\text { standards for discharge or reuse }\end{array}$ \\
\hline
\end{tabular}

Different types of water conservancy projects play different roles, and each type of project mentioned above usually does not exist alone, but in association with other types to fulfill its maximum function. As seen from the types and properties of water conservancy projects in the present day, there has been a transition from conventional functional projects to control-type projects, and further to ecological-type projects. The future direction will be ecological service-type projects. 


\subsubsection{Evolution of Equilibrium between Humans and River and Lake Systems}

While different types of water conservancy projects are built to satisfy the demand for water resources during social and economic development, mutual influences occur between humans, the ecological environment, social and economic systems, and hydraulic projects. The growing need for water resources drives the diversification of types and functions of water conservancy projects. The evolution of water conservancy projects in terms of type and function not only is inevitable to resolve the contradictions between social and economic development and the natural environment, but also is the result of constant adaptation to the human-water relationship. As water conservancy projects of different types and scales are constructed and put into operation, human needs arising from social and economic development are satisfied. In the meantime, there is a greater burden on the ecosystem as humans are transforming the Earth and river and lake ecosystems. This also increases the load on the natural ecological environment and compels changes to the human-nature relationship. In the system comprising humans, ecosystems, social and economic systems, and water conservancy projects, the human-nature (water) relationship is transitioning from one equilibrium to another, due to human activities.

\subsection{The Transition of Water Governance Principles Based on Human Cognition Concerning Water Conservancy}

During the evolution of the relationship between human needs and natural supply, the means mastered by humans to understand and transform nature (here referring to water conservancy projects) are also changing. Human cognition about water conservancy keeps progressing. Along with the progress in social production, economy, and technology, human cognition about water conservancy has changed dramatically. This further propels the evolution and development of water conservancy engineering.

\subsubsection{Evolution of Human Cognition of Nature}

As human society has evolved from ancient agricultural civilization to modern civilization, technological progress and productivity improvement have been stunningly impressive. In the beginning, people worshipped and feared nature, and gradually knew how to plunder from nature, and now people only want to get more from nature. Looking back on history, the evolution of the human-nature relationship can be divided into four major stages (including the present stage).

First stage: People were completely awed by the power of nature and conformed to nature in every way, enduring various natural disasters, such as drought and flood. The human-nature relationship was in a very weak initial equilibrium.

Second stage: After coping with nature for a long time, people gradually knew how to take the initiative to overcome, transform, or conquer nature and the environment. This began the enduring struggle between humans and nature. At this stage, the human-nature relationship was in temporary equilibrium (or false equilibrium).

Third stage: At the second stage, when humans had transformed nature to the extent that exceeded nature's carrying capacity, nature would fight back relentlessly. At this stage, humans were faced with the threat of ecosystem deterioration and imbalance. The human-nature equilibrium was gradually disrupted.

Fourth stage: The human-nature relationship is being reflected upon more seriously now than at any time before. There is a growing awareness of the importance of harmony between humans and nature. There is more effort to adjust human activities and behaviors so as to reduce the adverse impact on or further damage to nature. Ecological protection and repair campaigns have started in an attempt to improve the human-nature relationship and reach a new equilibrium.

\subsubsection{Human Cognitive Transformation Concerning River and Lake Governance}

Of all human relations with nature, river and lake ecosystems have the closest connection with human production activities, and water conservancy projects can best reflect the human-nature (water) relationship directly. The overall philosophy currently adopted for water conservancy development 
and water resource exploitation and governance has also evolved along the four-stage path described above. The evolutionary trajectory of human cognition about river and lake governance can be roughly described as follows: First, it is to "respect the rivers/lakes, conform to nature and inhabit by the water"; later it evolves into the belief that "man will conquer nature, transform and conquer rivers/lakes, and continuously expand the scale of water resource utilization." After the adverse impact of water conservancy projects on the river and later ecosystems begins to be understood, people are compelled to reflect on their imbalance and disharmony with water. Once this balance is disrupted, the first reaction is to adopt protection strategies and stop all actions of developing or demolishing dams (Figure 2). However, the complete suspension of water conservancy construction does not provide a radical cure and is in itself unsustainable. Human needs come first, and to satisfy human production and life needs, various means are required to exploit water resources. As a result, greater attention is given to improve the form, type, and service functions of water conservancy projects. Ecological restoration of damaged river and lake ecosystems has been initiated, and there is a growing awareness that protection should go hand-in-hand with development and that harmony between humans and water is a high priority (Figure 3).

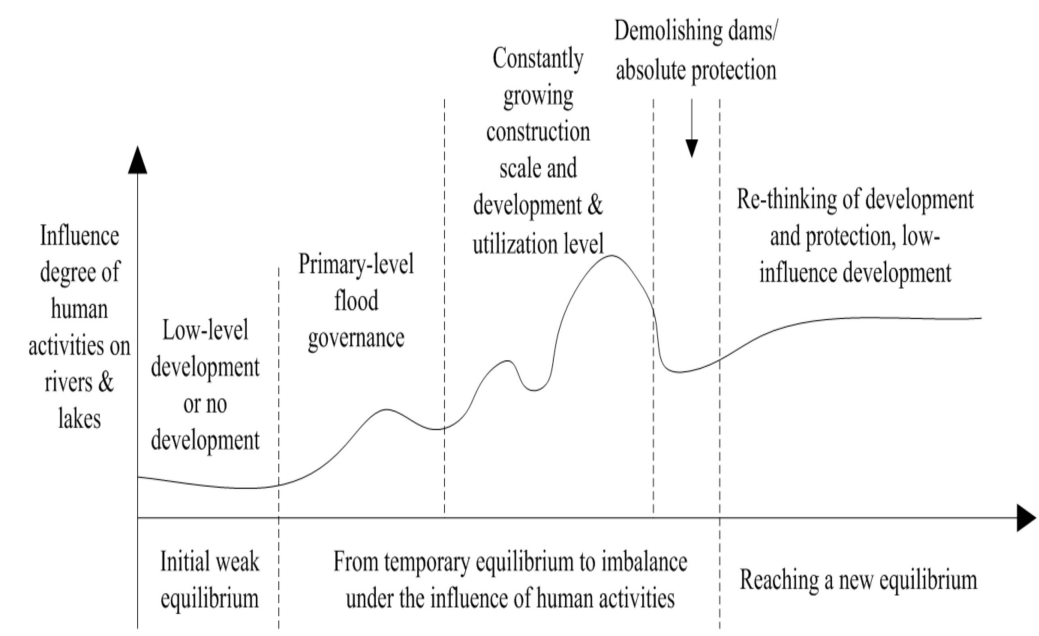

Evolution of relationship between man and rivers \& lakes

Figure 2. Evolution of equilibrium between humans and river and lake ecosystems.

\begin{tabular}{|c|c|c|c|c|}
\hline Cognition & $\begin{array}{l}\text { Respecting } \\
\text { rivers \& lakes }\end{array}$ & $\begin{array}{l}\text { Developing } \\
\text { rivers \& lakes }\end{array}$ & $\begin{array}{l}\text { Man begins to rethink about } \\
\text { man-water relationship }\end{array}$ & $\begin{array}{l}\text { Man lives in harmony } \\
\text { with water }\end{array}$ \\
\hline $\begin{array}{c}\text { Human } \\
\text { behaviors }\end{array}$ & $\begin{array}{l}\text { Humans live by rivers, } \\
\text { rely on rivers \& lakes } \\
\text { for survival and arc } \\
\text { threatened by natural } \\
\text { disasters } \\
\end{array}$ & $\begin{array}{l}\text { Maximizing benefits } \\
\text { and avoiding harms, } \\
\text { conquering floods, } \\
\text { and utilization water } \\
\text { resources }\end{array}$ & $\begin{array}{l}\text { Large-scale construction of water } \\
\text { conservancy projects; multi- } \\
\text { purpose utilization of water } \\
\text { resources }\end{array}$ & $\begin{array}{l}\text { Be kind to rivers, protect } \\
\rightarrow \text { water resources and repair } \\
\text { water ecosystem }\end{array}$ \\
\hline $\begin{array}{l}\text { Man- } \\
\text { river \& lake } \\
\text { relationship }\end{array}$ & $\begin{array}{l}\text { The human needs are } \\
\text { low under low social, } \\
\text { economic and technical } \\
\text { development levels; } \\
\text { man relies on the } \\
\text { natural rivers \& lakes } \\
\text { for survival and is } \\
\text { greatly influenced by } \\
\text { nature; the natural eco- } \\
\text { environment is good }\end{array}$ & $\begin{array}{l}\text { The social, economic } \\
\text { and technical levels } \\
\text { are progressing } \\
\text { constantly, and such } \\
\text { changes can be } \\
\text { accommodated by the } \\
\text { environmental } \\
\text { carrying capacity }\end{array}$ & $\begin{array}{l}\text { Construction and operation of } \\
\text { water conservancy projects and its } \\
\text { cumulative effect cause constant } \\
\text { disturbance to the river } \\
\text { ecosystem; the river ecosystem is } \\
\text { damaged, which further hinders } \\
\text { human development in terms of } \\
\text { water amount, water quality, } \\
\text { water ecology and water } \\
\text { environment }\end{array}$ & $\begin{array}{l}\text { The social and economic } \\
\text { needs are satisfied; in the } \\
\text { meantime, the ecological } \\
\text { and environmental crises } \\
\text { are being solved; both } \\
\text { man and water are } \\
\text { moving towards } \\
\text { sustainable development }\end{array}$ \\
\hline \multirow[t]{2}{*}{$\begin{array}{l}\text { Man- } \\
\text { river \& lake } \\
\text { balance }\end{array}$} & Initial balance & \multicolumn{2}{|c|}{$\begin{array}{l}\text { Human activities cause constant disturbance to the ecosystem } \\
\text { of rivers and lakes, and gradually resulting in imbalance }\end{array}$} & New balance \\
\hline & First stage & Second stage & Third stage & Fourth stage \\
\hline
\end{tabular}

Figure 3. Cognitive transformation concerning water conservancy projects during the development of the human-nature (water) interaction. 


\subsubsection{Pattern of Human Cognitive Transformation Concerning Water Conservancy Projects}

Nowadays, the underlying surfaces of rivers and lakes have been extensively transformed, leading to disharmony between humans and nature, which triggers self-reflection on nature, rivers and lakes, and water conservancy projects (corresponding to the third to fourth stages in Figure 3). "People-oriented" is the eternal theme of water conservancy development, and human cognition concerning water conservancy has undergone a transition process, as shown in Figure 4; that is, from disordered development guided by empiricism to absolute protection and suspension of all project construction guided by protectionism, and finally to equal importance attached to development and protection, which is typical of modern rationalism.

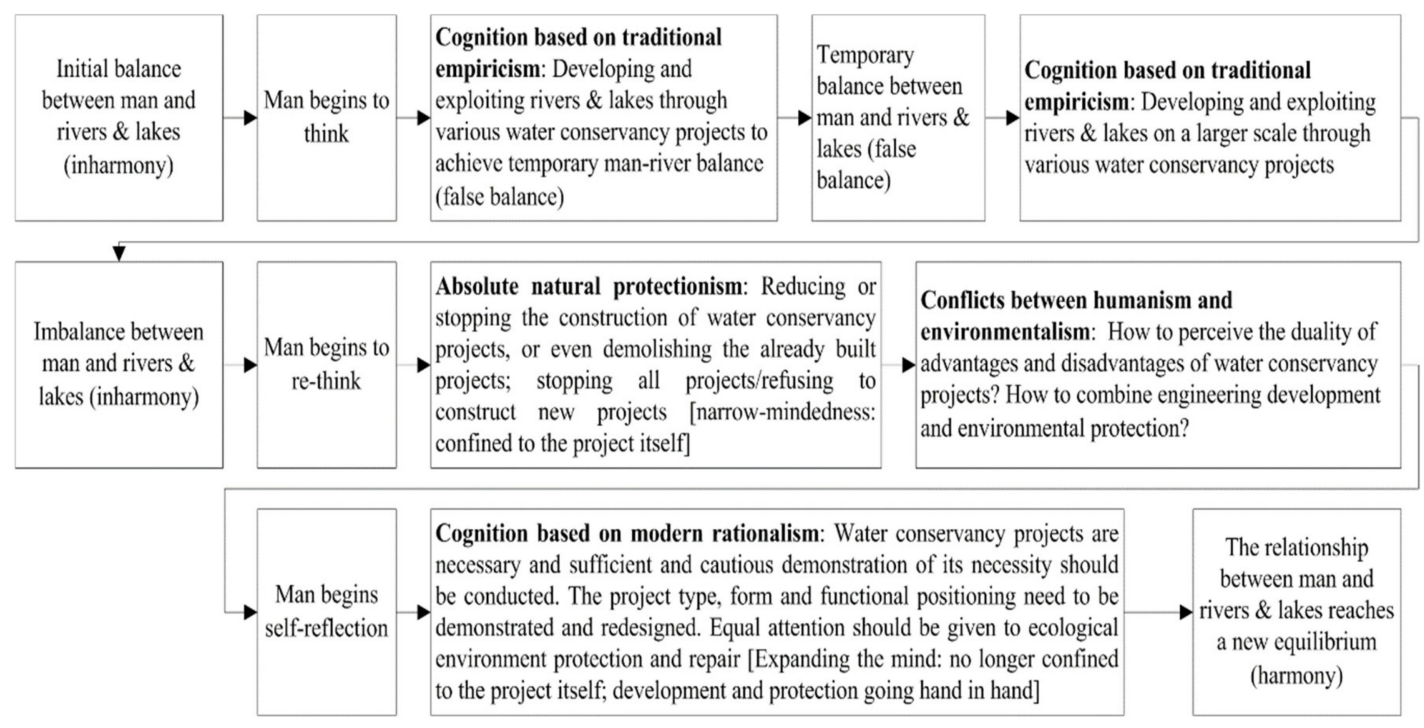

Figure 4. Pattern of human cognitive transformation concerning water conservancy projects.

In China, especially during the Great Leap Forward, several flood disasters were successfully warded off because of water conservancy projects, which further consolidated the belief that humans can conquer nature. After that, China began even more extensive construction of water conservancy projects [5]. The same situation also happened in the history of Western countries and lasted for nearly a century [21]. Driven by such belief, people are blinded to the potential harms of project construction, and this is the reason why many water conservancy projects also cause severe damage to the ecosystem while boosting human welfare. Since the 1950s, water governance principles have changed in foreign countries, with a greater emphasis placed on the protection of water resources and ecological construction than on development and exploitation. It was then fully realized that water conservancy construction should never be at the expense of ecological destruction and that efforts should be made toward project construction and the ecosystem. The United States was the first country to adopt a disaster relief strategy that combines engineering and non-engineering measures and to implement flood insurance. This practice was later accepted by other countries [22]. The core of such an approach is a transition from the absolute will to conquer nature to a combination of control and adaptation. It is advocated that the whole society should assume the appropriate risk of natural disasters and that flood relief that integrates comprehensive social measures will complement the benefits of water conservancy projects. Germany invented near-nature river management in the 1950s. The American scholar H.T. Odum proposed the concept of ecological engineering in the 1960s [23]. Over time, the engineering construction concept of conquering nature was gradually abandoned, and there was a transition to the concept of highlighting harmony between humans and nature and within society [24,25]. Modern water conservancy projects already consider ecological benefits as a top priority. While achieving the engineering goals, the maximum satisfaction of public benefits and 
ecological protection have become the most essential and constraining factors [5]. The ultimate goal is harmony between humans and nature.

At the self-reflection stage, there is a more long-term understanding concerning human conservancy projects from the perspective of modern rationalism. Both the advantages and disadvantages of water conservancy projects have been fully explored. Human cognitive transformation concerning water conservancy projects has four major features at this stage.

- Transformation 1: Turning harm into good (from disasters to resources)

At a time when the level of technical development is low and human needs are sufficiently satisfied by nature, floods are nothing but disasters to humans. All water conservancy projects are intended to avoid the harms of floods. As human needs grow excessively, nature can no longer satisfy humans. Floods, at this time, are considered beneficial for humans, and water conservancy projects are built to turn floods into resources. The core of flood resource utilization is the comprehensive and systematic application of engineering and non-engineering measures (policies, regulations, economy, management, technology, scheduling, etc.). Flood waters, which are usually discharged directly to the sea and cannot be retained, are partially transformed into inland waters that can be utilized under the premise of safety, economic feasibility, and social equity [26]. Then floods are no longer considered natural disasters, but exploitable resources. This is a dramatic cognitive transformation concerning how to cope with floods through water conservancy projects; that is, from flood prevention/control to turning floods into resources. In the past, water conservancy projects only blocked and defended floods, and now they can retain, store, and divert floods. Floods are no longer directly discharged without being utilized. In other words, there has been a transition from a blind struggle to save the land from floods to making space for water so that floods are better exploited to serve humans [27].

- Transformation 2: Turning from a traditional to a modern view of water conservancy

At different historical stages, humans have had varying levels of knowledge and technical expertise about water conservancy construction, as well as varying needs. Therefore, the cognition, positioning, and means of constructing and administering water conservancy projects have also varied. As human society and economy evolve, the transition from traditional to modern water conservancy is an inevitable consequence of water governance in modern society.

Water conservancy projects are built to reduce harm and create benefits; that is, to better exploit water resources. From ancient times to modern days, the large-scale building of water conservancy projects has been derived from the awareness that these projects contribute to the stable development of human society. However, in the early stages of development, people are only aware of the benefits of these projects, and are rarely aware of the potential harmful impact on surrounding regions [1]. Later, with increasing concern about issues, such as ecology, resettlement, land inundation, and others, environmental and social impact analyses have gradually become part of the design and demonstration stage of many water conservancy projects. At this stage, people no longer simply believe that water conservancy projects are all good. People begin to look at the impact of engineering dialectically and highlight environmental protection and ecological benefits. Since the middle of the 1970s, America, Brazil, Canada, and other Western countries have been talking about the environmental impact of water conservancy projects at the evaluation stage. The end of the 20th century marked a change in the perception of hydraulic engineering, especially in developed countries, with a shift in focus toward environmental issues, sustainability, and management [4]. China's Ministry of Water Resources released Several Regulations for Environmental Impact Evaluation of Water Conservancy Projects (Draft) in 1982. During the demonstration stage of the Three Gorges Project, the potential adverse impacts of the project attracted attention, and sufficient demonstration work was done. In recent years, however, absolute natural protectionism seems to prevail. According to this view, to protect the ecosystem, construction of water conservancy projects should be minimized or even completely abandoned. This neglects the needs of human development and overemphasizes environmental 
protection. The benefits of water conservancy projects are totally forgotten, and these projects are all bad according to this view. From this, the proposal for demolishing dams appears. Nevertheless, this also marks a constant cognitive evolution in the field of water conservancy as humans interact with nature. It represents a major transition from the traditional to the modern view of water conservancy.

The traditional view of water conservancy only emphasized the conquest and transformation of nature. As a result, the economic benefits were usually pursued at the expense of the ecological environment. People were little aware that nature has limited restoration capacity, and there was no scientific philosophy on water conservancy. In contrast, the modern view of water conservancy is guided by the concept of scientific development, which helps to coordinate the human-nature relationship, highlights environmental protection and ecological balance, and considers both present and future human needs. Driven by this view, the transition from extensive to intensive engineering activities takes place, and the latter better adapts to the modern economic development mode. The modern view of water conservancy is distinguished from the traditional view by the dialectical approach to the environmental impact of engineering projects and the importance of ecological protection.

- Transformation 3: Turning from a focus on engineering measures toward giving consideration to both engineering and non-engineering measures

Along with rapid social, economic, and technological development, the number and scale of water conservancy projects have soared in the past decades, and traditional project management has faced unprecedented challenges. For example, China has built many water conservancy projects over the past decades for the purpose of flood control and farmland irrigation. These projects do create enormous social, economic, and ecological benefits. While water conservancy construction is growing, still lingering is the understanding that everything is done once the projects are completed. Maintenance and repair of the projects, as well as non-engineering measures, such as policies and management are not given due attention. For this reason, many water conservancy projects are operating in poor and desolate conditions [28]. A similar situation has also occurred in the development process of water conservancy projects in other countries [29]. It is not until later that people are gradually aware of the severity and harm of equipment aging and that proper operation and management after project completion are crucial to maximizing benefits [30]. A combination of engineering and non-engineering measures is strongly advocated, with a greater emphasis on post-completion management, scheduling, and operation of projects so as to prolong their service life. This perspective of project life cycle management also represents the future development trend of water conservancy. At this stage, human cognitive transformation concerning water conservancy has an equal emphasis on project construction and operation and management, on engineering and non-engineering measures, and on project construction to life cycle management (covering every step from demonstration to construction, operation, maintenance, management, and scheduling, and even demolishing and quitting). Following this thought, project operation, maintenance, and management, as well as the comprehensive implementation of engineering and non-engineering measures, will be emphasized in the future. In particular, for proposed and new water conservancy projects, there should be sufficient demonstration in terms of necessity, project type, scale, functional efficiency, advantages and disadvantages, and input-output ratio. Equal attention will be given to project construction and the entire process of managing the project.

- Transformation 4: The concepts and principles of water governance are constantly being updated based on the current situation and water conditions of a country

As projects grow in number and scale, there is a cognitive transition concerning water conservancy. Recent years have seen increasing disharmony between humans and water, which triggers absolute natural protectionism. According to this view, no water conservancy projects should be built, and projects already built should be demolished to protect the ecological environment. The importance of protection is overemphasized and human development is neglected. All water conservancy 
construction is considered to be bad and must be completely stopped. However, this is not the future development trend of the human-water relationship, and it cannot adapt to social and economic development needs. Development is the eternal theme of human society. Only by sticking to the development concept of human orientation, comprehensiveness, harmony, and sustainability can we promote healthy economic and social development. Indeed, the situations vary from country to country, and the water conditions of different districts can also vary within one country. The human-water relationship should be reexamined based on the condition of the country and the water and by adopting a long-term perspective. The role of water conservancy projects in social and economic development needs to be rethought. To do this, a new principle of water governance is key. Guided by the concept of human-water harmony, humans should adopt a long-term view and update their cognition about engineering. The positioning of the development form and function of water conservancy projects should be done under the new context and new trend.

\section{What Is the Predicament in the Governance of Poyang Lake and How Can It Be Resolved?}

\subsection{Main Challenges and Ecological and Environmental Problems in Poyang Lake Basin}

As China's largest freshwater and alternatively filled lake, Poyang Lake has important ecological, social, and economic value in the Yangtze River Basin. The geographic location of Poyang Lake Basin is shown in Figure 5. The length of the lake in the north-south direction is $173 \mathrm{~km}$, the average width in the east-west direction is $16.9 \mathrm{~km}$, the shoreline is about $1200 \mathrm{~km}$, and the basin area is 162.2 thousand $\mathrm{km}^{2}$. Poyang Lake is affected by discharge from the five rivers upstream and the Yangtze River. The water level difference of the lake region between flood season and dry season reaches up to $15 \mathrm{~m}$. The water area of Poyang Lake in flood season is about $3000 \mathrm{~km}^{2}$ vs. less than $1000 \mathrm{~km}^{2}$ in the dry season. On the whole, the natural geographic characteristics can be described as follows: It is a lake with high water level and looks like a river with low water level; in flood season, the water is expansive and everywhere; and in the dry season, the water only forms a line [31]. Poyang Lake Basin has fertile soil, abundant produce, and social and economic prosperity. This region also has high agricultural productivity and large development potential. It has long been the major crop, oil, cotton, and fish production base in Jiangxi Province and the major crop production base in China. The Poyang Lake area has a highly developed industry and occupies an important status in Jiangxi Province. According to 2014 statistics, the population of Poyang Lake Basin was 12.34 million and arable land was 1.7 million acres, accounting for $27.2 \%$ and $24.4 \%$ of the province, respectively. The annual crop production of this region was 5.67 million tons, accounting for $26.4 \%$ of the province. The local GDP was 579.6 billion $\mathrm{RMB}$, accounting for $36.9 \%$ of the province.

Poyang Lake has been considered the "mother lake" of Jiangxi Province since ancient China, providing the major water source for local residents. Poyang Lake Basin has abundant natural resources and huge economic and social development potential. However, due to global climate change and the influence of human activities in recent years, Poyang Lake Basin now faces a series of ecological, hydrological, and environmental problems. For example, a decrease of the lake water system runoff into Poyang Lake, sand mining in water channels going into the Yangtze River, and impoundment of the Three Gorges Reservoir have resulted in an earlier arrival of dry season, a water level drop in the dry season, and a prolongation of the dry season [32]. Other influences, such as the backwater effect of floods and backward flow from the Yangtze River and human factors have brought about dramatic changes in the lake-river relationship [33]. Poyang Lake frequently experiences drought and flood disasters. The water ecology and water environment of the lake region have been deteriorating. The wetland area of Poyang Lake has been shrinking, with serious vegetation degradation, reduction in winter habitats for migratory birds, and impaired biodiversity. Drawing water for domestic and production activities has become difficult. Moreover, there is a shortage of irrigation water, depletion of fishery resources, and an apparent decline of navigation capacity in the lake region. As the water 
volume decreases, the bearing capacity of the water environment is also dwindling and the water quality is deteriorating. This poses a great challenge to local prevention of schistosomiasis [34].

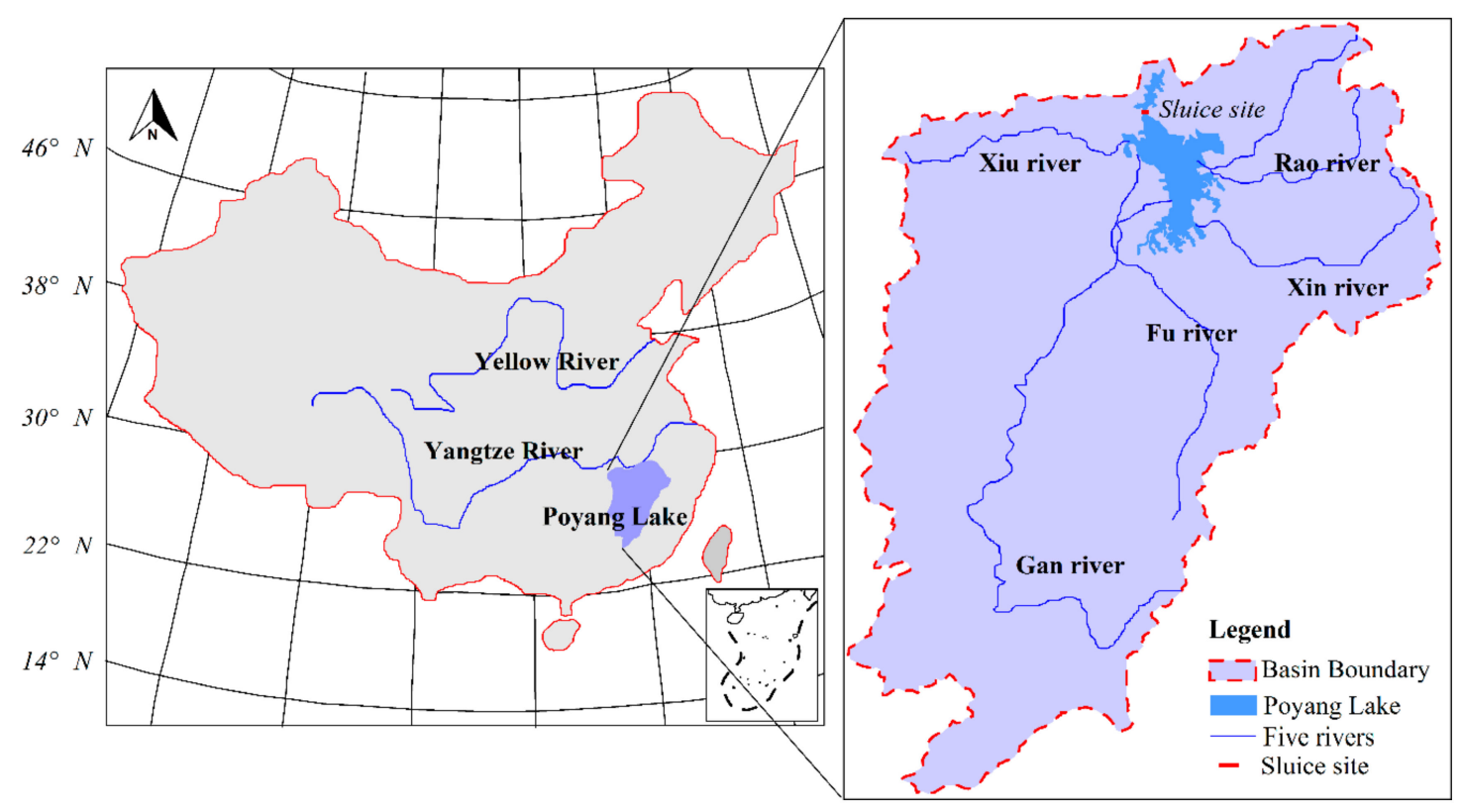

Figure 5. Geographic location of Poyang Lake Basin.

Ecological, hydrological, and environmental deterioration has considerably weakened the ecological system service function of Poyang Lake Basin, which further impedes reasonable and effective exploitation of natural resources in the lake region. This has become a major impediment to the local stability of social and economic development and even to the sustainable development of the entire Yangtze River Basin. Finding ways to avoid harm, improve the lake ecosystem, reasonably exploit the natural resources, and promote the healthy development of the lake region is an urgent task for the people of Jiangxi Province. Attention is also needed from a wider scope because of the important role of Poyang Lake in the Yangtze River Basin and international wetlands.

\subsection{History and Current Predicament in the Governance of Poyang Lake}

\subsubsection{History of Governance of Poyang Lake}

Governance and development activities around Poyang Lake have long been major concerns. From the later Han to the Qing Dynasty, many conservancy projects (e.g., protective embankments in lakeside areas and dikes and weirs) were constructed and river channel management activities were conducted so as to improve flood prevention, irrigation, and navigation conditions of the Poyang Lake Basin [35]. Since the 1940s, the problem of large water level variations in dry and flood seasons has been a difficult challenge. To solve this problem, discussions and demonstrations on whether and how to construct control projects have gone on for a long time. The timeline of the governance history of Poyang Lake (see Figure 6) can be divided into two major stages based on different development goals in different periods. 


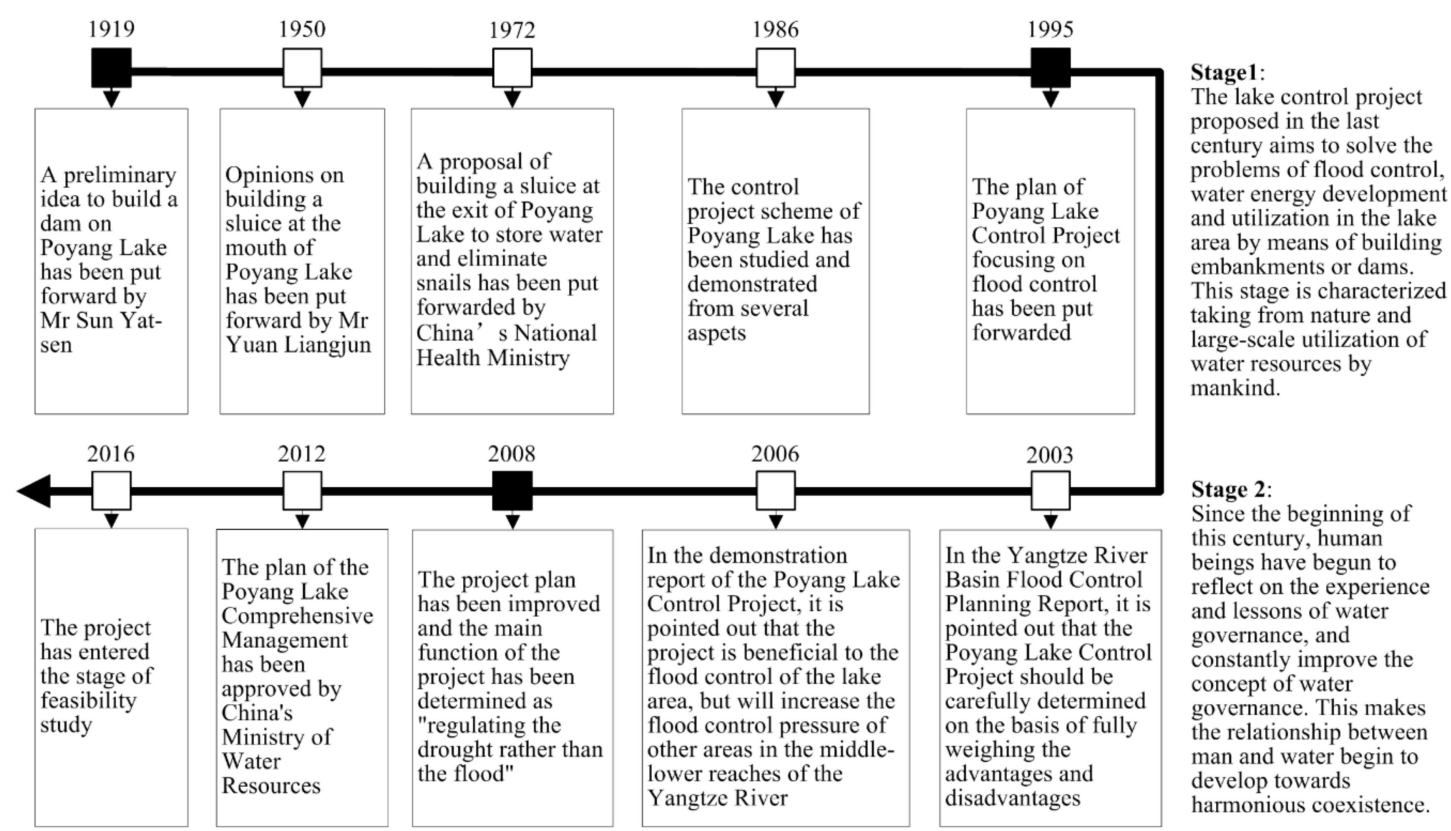

Figure 6. Timeline of governance history of Poyang Lake.

First stage: At the beginning of the last century, a preliminary idea to build a dam on Poyang Lake was put forward, with the purpose of connecting waterway transportation between Jiangxi and Guangdong Provinces. During the 1940s to 1950s, proposals were put forward from time to time to build a sluice project or a dam at the head of Poyang Lake, to keep out the backward flow of floods in the Yangtze River. Since the 1970s, in order to effectively prevent or control the frequent occurrence of flood disasters, rationally and fully exploit the abundant water and soil resources in the lake area, and realize sustainable and stable development of the national economy, the idea of building a Poyang Lake control project put forward by Jiangxi Province has been studied and demonstrated by relevant departments. After China's reform and opening up, the demonstration work of the Poyang Lake control project formally started and the proposal for constructing a multipurpose hydraulic project at the water channel going into the Yangtze River was proposed in 1995. The multiobjective functions of the project include flood control, power generation, shipping, irrigation, water supply, etc. The intended purpose is to solve the above-mentioned problems and improve the water ecology of Poyang Lake. The content of this proposal was to use a pump station in the flood season to lower the water level and a floodgate in the dry season for impoundment of water, so as to improve shipping, irrigation, and the water supply. However, as with the construction of other hydraulic projects, the potential environmental impact attracted the attention of many environmentalists. In 2002, some experts raised doubt about the Poyang Lake Hydraulic Project. The justification was that if the floodwaters in Poyang Lake were discharged in the flood season to relieve the pressure on the levee, it would cause a greater burden of flood prevention for other provinces in the lower reaches of the Yangtze River. Furthermore, there would be adverse ecological and environmental impacts. Thus, began the extensive controversy over the Poyang Lake Hydraulic Project, and construction of this project was temporarily halted.

Second stage: As the Three Gorges Dam was finished and put into operation, there was extreme pressure on flood prevention, water supply, and ecological service functions for Lake Poyang. With the deepening of cognition, and based on the requirements of social and economic development and environmental protection of the lake, in 2008, Jiangxi Province made another proposal for the Poyang Lake Hydraulic Project, an open full-sluice project of class I. The sluice is located at the waterway of the lake going into the Yangtze River, as shown in Figure 5, and an aerial view of the design proposal is shown in Figure 7. It breaks through the original concept of taking flood control of the Poyang Lake area as the main goal and forms a new concept of taking the comprehensive protection and 
development of water resources as the main goal, i.e., regulating the drought rather than the flood. The design adopts the method of building a sluice instead of a dam, adjusts the project type from the original dam to an open full sluice. Its functional position is as follows: To elevate the water level of Poyang Lake and the water carrying capacity in the dry season, and improve water supply, irrigation, ecosystem, fishery, shipping, schistosomiasis prevention and control, and water resource protection. It is a comprehensive project intended to restore and reasonably regulate the river-lake relationship. According to the proposal, this project would regulate in the dry season rather than flood season. Compared with the first stage, there are improvements in the design concept in the following two aspects: First, during the flood season, when floods are high in the Yangtze River, the sluice will be fully opened to connect the rivers and lakes for regulation and storage of floodwater. This is conducive not only to flood diversion, but also to the spawning of migratory fish. Second, wetlands will be taken into consideration when this hydraulic project is built. The lake water is regulated and stored in the dry season, and the water level of Poyang Lake is controlled to best preserve wetlands and maximize ecological benefits. In recent years, there have been more or less dissenting voices from environmental organizations, news media, etc., on the Poyang Lake Project from the perspective of the living environment and wetland protection for Yangtze finless porpoise and migratory birds [36,37]. On the basis of acknowledging opinions and suggestions from various aspects, and weighing the pros and cons, the demonstration of the Poyang Lake Hydraulic Project has been stepped up by several national administrative departments, including the Ministry of Water Resources, the National Development and Reform Commission, and the Ministry of Environmental Protection. In the process of demonstration, the planning idea of the project is constantly adjusted, the design scheme is optimized accordingly, and the construction concept is constantly undergoing innovation. These continuous improvements include the functional position, sluice type, regulation mode, and others. At present, the project has entered the feasibility study stage.

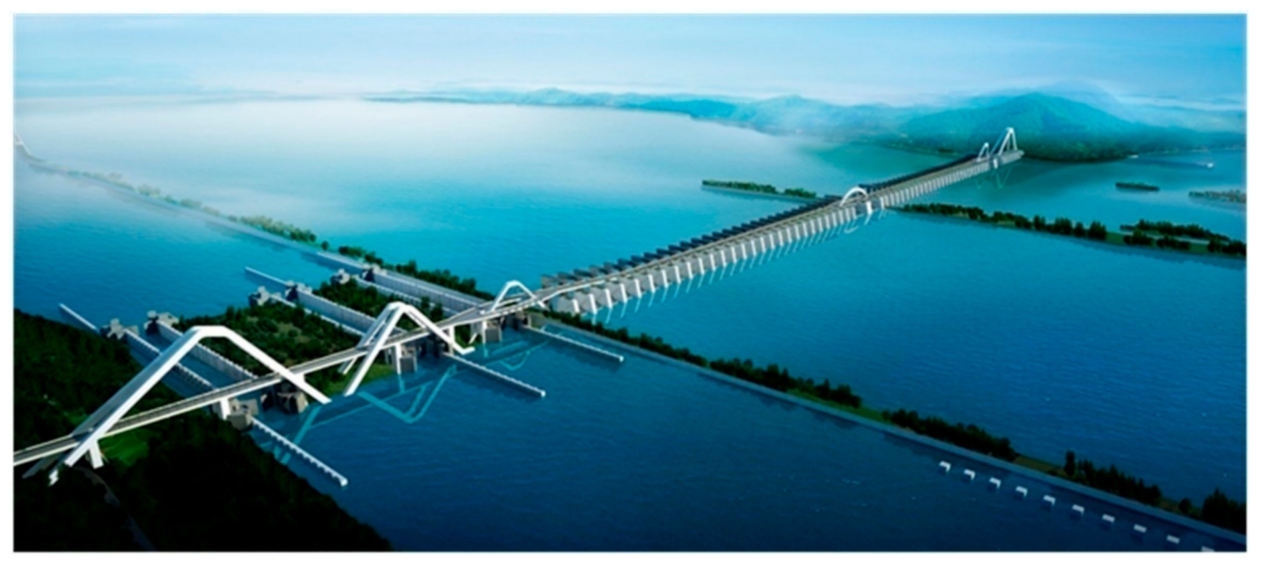

Figure 7. Aerial view of the design proposal.

\subsubsection{Current Predicament in the Governance of Poyang Lake}

The following features are described as seen from the demonstration process at the two stages described above:

The first predicament in the governance of Poyang Lake is that there is a contradiction between local social and economic development needs and opposition by environmentalists. Jiangxi Province is less developed socially and economically, and its level of development still has a high dependence on Poyang Lake resources (the watershed area of Poyang Lake Basin accounts for about $97 \%$ of the total area of Jiangxi). There is still a need for local social and economic development. However, environmentalists oppose the proposal only on the grounds of wetland ecology protection without considering the practical needs, which is hindering the process of governance of Poyang Lake. 
The second predicament in the governance of Poyang Lake is identifying and balancing the ecological threat vs. the ecological and environmental protection function of the hydraulic project. Water conservancy projects, on the one hand, are intended to solve some ecological and environmental problems and exert a protective effect, and, on the other hand, transform nature (rivers and lakes), and certain interference and stress (adverse ecological impacts) seem to be inevitable. So, the question is how to balance the project's ecological protection function and the ecological threat. That is where some measures (engineering and non-engineering) are needed to avoid or relieve the adverse impact of water conservancy projects on the river and lake ecosystem.

\subsection{Human Self-Reflection on the Challenges Encountered in Poyang Lake Basin in the Era of Modern Water Conservancy}

The evolution of the human-water relationship in Poyang Lake governance follows the path in Figures 2 and 4. The progress of water resource governance has been constantly reconsidered and updated in practice. It has been recognized that "absolute protectionism" is definitely not the solution to the urgent water-related and ecological problems of the current Poyang Lake Basin, because it is not a sustainable approach for either the ecosystem or the local residents, and water conservancy projects are still needed to face these problems. Engineering measures are an indispensable means to optimize the water carrying capacity of Poyang Lake in the dry season, improve the livelihoods of local residents, and maintain local biodiversity. Appropriate water conservancy projects (complemented by non-engineering measures) are important to completely solve the considerable water level difference in dry and flood seasons and to make full use of water resources.

As far as the governance of Poyang Lake is concerned, the following questions need to be answered given the current underlying situation of the river basin: What are the most suitable measures? How should the engineering measures be implemented? What is the appropriate type, scale, and functional position of water conservancy projects? How should demonstration and design be conducted from multiple perspectives to place equal importance on development and protection at each stage of project life cycle management (construction, operation, management, and other aspects of the project) without creating excess adverse impact while maximizing the comprehensive benefits? Looking back on the history of the Poyang Lake Hydraulic Project, the following suggestions are made.

\subsubsection{The Proposal of Poyang Lake Hydraulic Project Has a Background of Realistic Demand}

Considering the first predicament of Poyang Lake governance, cognitive transformation concerning water conservancy is crucial to clearly understand the evolutionary pattern of the human-water relationship. From the perspective of modern water conservancy, a great deal of infrastructure is needed to promote stable and fast social and economic development in the context of China's ongoing extensive social construction. Only with an improvement of infrastructure can stable development be guaranteed in every respect. In this sense, it is an important and realistic need for local people to support the proposal for constructing the Poyang Lake Hydraulic Project. First, along with the evolution of the relationship between the Yangtze River and Poyang Lake, the water level of the lake has to be controlled through water conservancy, and this is highly important for both Poyang Lake in the dry season and the Yangtze River in the flood season. Second, the Poyang Lake Hydraulic Project is necessary to promote the social and economic development of Jiangxi Province. Third, in the functional positioning of the Poyang Lake Hydraulic Project, ecology first and human-water harmony are imperative to realize and maintain a new balance.

\subsubsection{A Detailed Demonstration of the Hydraulic Project to Be Built Is Necessary}

Before the construction of any project (including the Poyang Lake Hydraulic Project), a sufficient scientific demonstration is necessary, and the demonstration of some projects may even last for a long time. For example, the time span from the initial proposal for the Three Gorges Hydroelectric Complex project to its formal construction was 75 years. The Poyang Lake Hydraulic Project has lasted for 
100 years since it was first proposed in 1919. The tentative plan of the Poyang Lake project has a long history and much controversy. Therefore, with the deepening of human cognition about lake governance, the project plan has been adjusted in many ways. These adjustments include changing the function position from flood control to drought control, the project type from the dam to the sluice, the scheduling mode from annual to phased control, etc. In this long discussion process, the functional orientation and scheduling mode of the project are optimized constantly.

3.3.3. Continuous Optimization of the Poyang Lake Hydraulic Project Is the Result of the Evolution of Human Cognition

The solution to the second predicament of Poyang Lake governance is to adopt new concepts and principles of water governance to guide the practice in the new era. The Poyang Lake Hydraulic Project is not a single-purpose project, but a multipurpose ecosystem-service hydraulic project. During project design and demonstration, not only the social and economic benefits, but also the ecological benefits should be considered. An ecosystem-service hydraulic project will inevitably lead to human-water harmony. The functional positioning of the project must be based on a long-term perspective, comprehensive consideration, and sufficient demonstration. The benefits of a water conservancy project should not be completely ignored, due to its potential adverse impacts. While identifying and analyzing some of the potential problems in project construction, the future benefits to the ecology, economy, and society (e.g., fishery, shipping, hydropower, agricultural irrigation, schistosomiasis prevention and control, and cultural tourism) after the project is completed should be considered and integrated. Moreover, there should be continuous efforts to ease the inevitable adverse impacts brought about by construction through scientific measures. Alternatives can be sought and used for salvage or to minimize the harm by optimizing the scheduling during project operation through non-engineering measures.

In a word, the ultimate purpose of hydraulic project construction is to achieve harmony between humans and nature. Apart from the conventional functions, the Poyang Lake Hydraulic Project should also be able to maintain a healthy lake ecosystem. By giving due attention to the ecological impact of the project, we can finally achieve human-water-ecosystem harmony in the new era and make this an ecosystem-service hydraulic project that benefits the country and the people and can be developed sustainably.

\section{Discussion}

\subsection{Some Discussion on Human Cognitive Transformation Concerning Water Conservancy}

Water plays a major role in our perception of the environment because it is an indispensable element of human life [4]. Human cognition concerning water conservancy has evolved following a certain route and along with the times. Humans have different cognitive levels concerning the river and lake ecosystem in different periods. As the need for and technical level of river and lake resources vary, so do the concepts and principles of water governance. In light of this, human cognitive transformation concerning water conservancy is inevitable. Summarizing the inevitability of this cognitive transformation is also an in-depth process of understanding the development of the human-water relationship, which has important educational and guiding significance. It can guide humans to a new understanding of water conservancy projects and new ideas on how to treat these projects in the future with scientific value.

\subsubsection{Human Cognitive Transformation Is Driven by Social and Economic Progress}

Hydraulic engineering projects have traditionally been carried out from a predominantly technical point of view, which on occasion ignores the needs of the territory in which they are based and the possibilities that water resources provide as a development factor. Projects that were not adequately suited to the needs of the environment and its population have led to many issues that have had direct 
effects on their implementation and operation [38]. During the long course of historical evolution, human cognition about water conservancy (including the type and function of projects) has also changed dramatically, which in turn propels further evolution and development of water conservancy. Currently, the technical challenges faced by hydraulic engineers are formidable [4], because they have to adapt to the needs of the times, considering not only the technical and economic benefits of engineering measures, but also the environmental and social variables involved in hydraulic engineering projects. This kind of sustained research effort is essential. In addition, for water conservancy projects that have been or are going to be built, appropriate risk identification and evaluation analyses [39] should be carried out centered on the project itself and its potential impacts, so as to provide a basis for decision-making by project builders or planners.

4.1.2. Human Cognitive Transformation Is the Result of Interaction and Adaptation between Humans and Nature

Human thoughts and principles of water governance vary with the level of civilization. As human society has evolved from agricultural to industrial and finally to ecological civilization, there has been a succession of complying with nature, adapting to nature, resisting nature, being resisted by nature, complying with nature, and finally respecting nature. The relationship between water conservancy construction and the ecological environment can be coordinated only on the basis of respecting natural laws, and this is a prerequisite for achieving sustainable development.

Research results on the evolution of water conservancy projects and human cognitive transformation (Figures 1-4) can be used in a wide range of application in practice. In the proposal and planning stage, they will be helpful in determining whether or not to build a project. In the design phase, they can guide how to build a project. In the operation and maintenance stage, they can help in deciding whether additional non-engineering measures are needed. These results can provide not only a scientific basis for government decision-making, but also valuable theoretical guidance for other stakeholders concerned about project construction.

\subsection{Some Discussion on the Construction Proposal of the Poyang Lake Hydraulic Project}

China has paid more attention to the research and practice of eco-environmental protection in the process of water conservancy and hydropower development, and has reaped marked results [2]. President Xi Jiping pointed out in 2013 that mountains, waters, forests, farmlands, and lakes are living communities and that regulating the use of natural resources and ecological repair must obey natural laws. Similarly, the governance of Poyang Lake also has to respect natural laws and the evolution of the human-nature relationship. Based on the above analysis of human cognitive transformation and combined with the current predicament of Poyang Lake governance, the authors suggest the following perspectives for the demonstration of the Poyang Lake Hydraulic Project.

\subsubsection{Understanding Modern Water Conservancy Projects from the Perspective of Human-Water Harmony}

China is currently at the primary stage of socialism and will continue like this for a long time. Development remains China's top priority, and water conservancy will be its major task in the future. The core of water conservancy lies in the concept of human-oriented needs. Under the general context of sustainable and ecological development, we should place equal importance on water resource development and exploitation and the adverse impacts on the ecosystem. That does not mean that natural protectionism is right [5]. Although traditional water conservancy projects create enormous social and economic benefits in flood control, hydropower, irrigation, water supply, and shipping, the original river and lake ecosystem is damaged. In modern times, water conservancy should return to the essence and evolve toward the goal of ecosystem-service projects so as to create greater ecological benefits. As far as the Poyang Lake Hydraulic Project is concerned, the main goal is to ensure stable social and economic development around the lake area. A number of barriers to stable development are 
expected to be overcome by the project through flood control, water supply in the dry season, shipping, and schistosomiasis prevention. In the meantime, the ecological health of the Poyang Lake area is to be preserved. Harmony between humans and nature only exists under a certain level of civilization. To achieve this goal, it should be fully recognized that humans and nature are part of one living community and that humans must always respect, comply with, and protect nature. Harmony is part of this goal. In the ecological civilization, humans must maintain the sustainability and renewability of water, as well as the integrity of the ecosystem while pursuing fast economic growth. On this basis, we can hope to achieve the sustainable development goal of human-nature harmony.

\subsubsection{Developing Ecological and Service-Oriented Water Conservancy Projects}

The Poyang Lake Hydraulic Project should be developed in an ecological and service orientation, and its multifunctional and comprehensive properties should be assured first. On the one hand, multiple needs should be satisfied during its life cycle to realize the maximal benefit. On the other hand, this project should improve the water resources and water carrying capacity of Poyang Lake during the dry season. Besides, improving the water supply, irrigation, ecological environment, fisheries, shipping, and schistosomiasis prevention and control; restoring and regulating the river-lake relationship; easing ecological pressure; and protecting water resources are also among the primary tasks. Third, the basic principle of regulating the dry season but not floods should be adopted while satisfying various needs. Water resources should be fully utilized, especially floods in the Yangtze River during the flood season. Engineering measures, such as impoundment and diversion can be used to turn floods into resources. Water regulation and storage in the dry season are also important for improving water carrying capacity and quality in Poyang Lake in the dry season.

\subsubsection{Comprehensive Application of Project Management Measures Based on the Life Cycle Theory}

The proposed Poyang Lake Hydraulic Project should be viewed from a dialectic perspective. After identifying the environmental impacts during and after construction, it is important not to overestimate the drawbacks. Rather, some scientific means (e.g., auxiliary engineering or non-engineering measures) can be utilized to avoid or reduce the harm. For example, habitats for migratory birds may be affected by impoundment during the dry season. To solve this problem, a certain habitat area can be preserved by artificially controlling the water level. New habitats can be planned in adjacent regions according to the behaviors and environmental adaptability of migratory birds. The hydraulic project proposal should be viewed and demonstrated according to the life cycle management theory. Each stage of the project, from demonstration and construction to operation, maintenance, administration, and even demolishing and quitting, should be considered. The relevant management and maintenance personnel should be in place before the project is completed so as to ensure the implementation of the management and responsibility systems and a seamless transition from construction to operation and management. During project operation, regular check-up and maintenance of equipment are important to prolong service life. Furthermore, the operation scheme should be adjusted at different stages, based on different goals, to achieve the combination of engineering and non-engineering measures. Thus, the life cycle management of the project can be achieved, thereby maximizing the benefits and making it the centennial project that benefits the country and its people.

\section{Conclusions}

Water conservancy projects are an important way to understand and transform nature, as well as the pathways by which the human-nature (rivers and lakes) relationship evolves. The conflict between traditional water conservancy projects and ecological stress has drawn unprecedented attention. Weighing the advantages and disadvantages of water conservancy projects and bringing the ecosystem service functions of the project to their full capacity are major concerns for technicians, administrators, politicians, environmentalists, and other stakeholders. Only looking at one aspect of water conservancy projects, either the advantages or disadvantages, is unwise. Social and economic development is still 
China's top priority. Harmony and sustainability between humans and nature can be only built upon respect for social development law, the evolution pattern of the human-nature relationship, and the correct perception of the roles of water conservancy.

The key to avoiding the harms and maximizing the benefits of water conservancy projects is to combine engineering and non-engineering measures, as well as technical and administrative measures. Today technical means are no longer a problem, though the positioning of the project requires caution. A single purpose or economic benefits alone should never be the target of pursuit. Instead, ecological benefits should be prioritized. It should be noted that the demand for hydropower varies with different stages of social and economic development and levels of industrial and agricultural production. Building an ecologically friendly technical system and ecosystem-service water conservancy will be the future path to sustainable development. Striking a balance between human social and economic development and preserving ecosystem health is crucial for the goal of sustainable development.

The relationships between humans and lakes and between the river (Yangtze River) and the lake (Poyang Lake) have gradually changed, due to the development and utilization of lake resources by people living in the Poyang Lake basin. Water-related issues (especially low-water periods) have become increasingly prominent in recent decades. In this context, the proposal for building a dam or sluice in the waterway of Poyang Lake to the Yangtze River has repeatedly been put forward by Jiangxi Province to improve flooding or low-water problems through engineering measures, but it has frequently faced opposition from environmentalists at home and abroad. In the face of growing low-water problems of Poyang Lake today, we should not blindly reject or randomly launch any water conservancy project, but wisely adopt the modern perspective of water conservancy and water governance principles. When considering water conservancy projects, we should fully consider the four cognitive transformation rules of such projects formed in humans' historical development. The proposal for constructing the Poyang Lake Hydraulic Project has its realistic demand background during the course of development. A detailed demonstration of this proposal is highly necessary, and its type and functional positioning should be based on a long-term perspective and comprehensive consideration.

Author Contributions: Conceptualization, Y.W. and L.G.; Data curation, Y.W.; Formal analysis, Y.W., P.J. and X.C.; Investigation, Y.W.; Supervision, Z.X.; Writing-original draft, L.G.; Writing-review and editing, L.G.

Funding: This research was funded by the Fundamental Research Funds for the Central Universities (Nos. 2018B20214, 2018B41914), Science and Technology Projects of the Water Resources Department of Jiangxi Province (Nos. KT201701 and KT201538), National Natural Science Foundation Projects of China (Nos. 41401010, 41401011), and Program for Changjiang Scholars and Innovative Research Team in University (No. IRT_17R35).

Acknowledgments: The authors acknowledge the constructive comments from anonymous reviewers, which led to the improvement of the paper.

Conflicts of Interest: The authors declare no conflict of interest.

\section{References}

1. Pan, J.Z. Problems and outlook of China's achievements in water conservancy construction. Chin. J. Eng. Sci. 2002, 4, 42-51.

2. Jia, J.S. A Technical Review of Hydro-Project Development in China. Engineering 2016, 2, 302-312. [CrossRef]

3. Zhang, B.; Tian, P.D.; Jin, L.X. An overview and inspiration of international experience in coordinating the relationship between hydropower construction and ecological environment. J. Econ. Water Resour. 2010, 28, 49-53, 77.

4. Hubert, C. Hydraulic engineering in the 21st century: Where to? 13th Arthur Ippen awardee, IAHR Member. J. Hydraul. Res. 2007, 45, 291-301. [CrossRef]

5. Liu, N. Understanding about hydraulic constructions aimed to achieve man-nature harmony. Chin. Water Resour. 2007, 4, 13-17.

6. Li, L.X.; Deng, X.Z.; Zhan, J.Y.; Li, Y.J. Importance evaluation of ecosystem service of Poyang Lake Valley: An analysis based on AHP. J. Anhui Agric. Sci. 2008, 36, 8786-8787. 
7. Tu, M.-C.; Smith, P. Modelling pollutant buildup and washoff parameters for SWMM based on land use in a semiarid urban watershed. Water Air Soil Pollut. 2018, 229, 121. [CrossRef]

8. Zhang, J.; Li, S.Y.; Dong, R.Z.; Jiang, C.S.; Ni, M.F. Influences of land use metrics at multi-spatial scales on seasonal water quality: A case study of river systems in the Three Gorges Reservoir Area, China. J. Clean. Prod. 2019, 206, 76-85. [CrossRef]

9. Wang, J.L. Polder and related flood prevention engineering technology in the middle and lower reaches of the Yangtze River in Ming and Qing Dynasties. Agric. Hist. Chin. 1991, 2, 37-42.

10. Li, F.F.; Pan, S.Y.; Lai, G.Y.; Wu, Q. Simulation Study on the Influence of the Proposed Poyang Lake Water Control Project on the Lake and Lake Flow. Jiangxi Sci. 2019, 37, 1-90, 115.

11. Li, H.H. Changes of water level in main lake area of Poyang Lake and in dish-shaped sub-lake and their impacts on water quality. Resour. Environ. Yangtze Basin 2018, 27, 1298-1306.

12. Li, B.; Yang, G.S.; Wan, R.R.; Li, H.P. Hydrodynamic and water quality modeling of a large floodplain lake (Poyang Lake) in China. Environ. Sci. Pollut. Res. 2018, 35, 35084-35098. [CrossRef]

13. Jiang, H.M.; Wang, Z.Z.; Zhang, X.P. Discussion of China's comprehensive planning and governance of urban river environment. J. Northwest AEF Univ. Soc. Sci. Ed. 2006, 34, 125-128.

14. Yu, K.J. Water ecology infrastructures of beautiful China: Theory and practice. J. Poyang Lake 2015, 1, 5-18.

15. Rogers, J.D. Hoover Dam: Scientific studies, name controversy, tourist attraction, and contributions to engineering. In Proceedings of the Hoover Dam 75th Anniversary History Symposium, Las Vegas, NV, USA, 21-22 October 2010; pp. 216-248.

16. Abu-Zeid, M.A.; El-Shibini, F.Z. Egypt's high Aswan dam. Int. J. Water Resour. Dev. 1997, 13, $209-218$. [CrossRef]

17. Zhang, G.D. The Three Gorges Project of the Yangtze River. Chin. J. Eng. Sci. 1999, 1, 78-80.

18. Shu, S.Y. Major reform and major governance for major disasters. Jiangxi Soc. Sci. 1998, 11, 1-4.

19. Han, B.P. Reservoir ecology and limnology in China: A retrospective comment. Lake Sci. 2010, 22, 151-160.

20. Zheng, L.D.; Tan, X.M.; Jiang, C. China Water Conservancy Encyclopaedia: Volume of Water Conservancy History, 1st ed.; China Water \& Power Press: Beijing, China, 2004.

21. Dong, Z.R. Development stage and some thoughts about river projection. Chin. Water Resour. 2004, $17,16-17$.

22. Zhou, K.Y.; Tan, X.M. Historical study and drawing lessons from flood prevention principles. Chin. Water Resour. 2000, 9, 39-41.

23. Odum, H.T. Ecological tools and their use: Man and the ecosystem. In Proceedings of the Lockwood Conference on the Suburban Forest and Ecology; Waggoner, P.E., Ovington, J.D., Eds.; The Connecticut Agricultural Experiment Station Bulletin: New Haven, CT, USA, 1962.

24. Dong, Z.R. Development history and trend of ecological engineering for river governance. Water Resour. Hydropower Eng. 2004, 35, 39-41.

25. De Vriend, H.J.; van Koningsveld, M.; Aarninkhof, S.G.J.; de Vries, M.B.; Baptist, M.J. Sustainable hydraulic engineering through building with nature. J. Hydro-Environ. Res. 2015, 9, 159-171. [CrossRef]

26. Xiang, L.Y.; Wei, Z.M. Turning flood into resources: Concept, pathway and strategy. Water Resour. Dev. Res. 2005, 5, 24-29.

27. $\mathrm{Xu}, \mathrm{J} . J . ;$ Sang, L.H. Discussion of flood resources utilization scheme of Poyang Lake oriented towards ecological water conservancy. In Proceedings of the 2009 annual academic conference of Water Resources Committee of Chinese Hydraulic Engineering Society, Dalian, China, 4 December 2009.

28. Tan, S.K. New concept of urban water governance: Transition of concept of water conservancy engineering from the perspective of Beijing's water system governance project. Beijing Water Resour. 2000, 1, 7-10.

29. Kuznetsov, V.A.; Zotov, V.M.; Novozhenin, V.D.; Fain, I.I. Hydraulic power engineering in Russia: Problems and solutions. Hydrotech. Constr. 2000, 34, 1-12. [CrossRef]

30. Rui, X.F.; Liu, N.N.; Zhu, J.J. Understanding about some problems in water conservancy and the development of water conservancy science. Adv. Sci. Technol. Water Resour. 2011, 31,1-4.

31. Hu, Z.P.; Ge, G.; Liu, C.L.; Chen, F.S.; Li, S. Structure of Poyang Lake wetland plants ecosystem and influence of lake water level for the structure. Resour. Environ. Yangtze Basin 2010, 19, 597-605.

32. Lv, T.T.; Chen, J.R.; Ren, S.S. Analysis of water level variation in Poyang Lake after the Three Gorges Project operation. J. Water Resour. Water Eng. 2018, 29, 41-45.

33. Wang, Z.H.; Fan, H.X.; Zhum, L.J.; Liu, B.B. Review on the influence to the Poyang Lake by flowing backward of the Yangtze River and the study process of micro physical model. J. Sediment Res. 2019, 44, 59-66. 
34. Xia, S.X.; Yu, X.B.; Liu, Y.; Jia, Y.F.; Zhang, G.S. Current Issues and Future Trends of Poyang Lake Wetland. Resour. Environ. Yangtze Basin 2016, 25, 1103-1111.

35. Hu, J.A. Water administration of Poyang Lake at early stage. Jiangxi Hydraul. Sci. Technol. 1984, 4, 014.

36. Ge, G.; Ji, W.T.; Liu, C.L.; Xiong, S.; Wu, Z.Q. Hydraulic project and wetland ecological protection in Poyang Lake. Resour. Environ. Yangtze Basin 2010, 19, 606.

37. Zhang, P. Construction and influence analysis of ecological water conservancy hub project in Poyang Lake. J. Jiujiang Univ. (Nat. Sci. Ed.) 2008, 6, 87-88.

38. De Nicolas, V.L. Towards a transformational hydraulic engineering project for the territory: A focus on the Working with People (WWP) model. Land Use Policy 2016, 54, 246-252. [CrossRef]

39. Pietrucha-Urbanik, K.; Tchórzewska-Cieślak, B. Approaches to Failure Risk Analysis of the Water Distribution Network with Regard to the Safety of Consumers. Water 2018, 11, 1679. [CrossRef]

(C) 2019 by the authors. Licensee MDPI, Basel, Switzerland. This article is an open access article distributed under the terms and conditions of the Creative Commons Attribution (CC BY) license (http://creativecommons.org/licenses/by/4.0/). 